\title{
THE INFLUENCE OF DIFFERENT SOIL Cultivation ON Fuel CONSUMPTiON AND THE GROWTH OF BUCKWHEAT
}

\author{
Vindis, P. ; LAKOTA, M. \& STAJNKO, D.
}

Abstract: In this research the influence of different ways of soil tillage and sowing of buckwheat on the fuel consumption was investigated. In addition, the influence of tillage on the germination of buckwheat, the number of weeds and the germination of the crop was investigated. For soil tillage the standard New Holland T6020 DELTA tractor, the 4-furrow Lemken VariOpal 6 plough and the Lemken Smaragd 9 chisel were used. Sowing was effected with New Holland TN75D tractor and Lemken SAPHIR 7 Autoload seeder machine. The average fuel consumption when chiseling the soil with chisel was 11. $26 \mathrm{l} / \mathrm{h}$ and $31.05 \mathrm{l} / \mathrm{ha}$ when ploughing. The buckwheat emergence on ploughed soil was $90.1 \%$, on chiselled soil $72.3 \%$ and $68.4 \%$ in direct sowing. The plant grew higher on ploughed soil than on chiselled soil. It was found out that the conventional way of soil tillage is the most appropriate for growing buckwheat.

Key words: soil tillage, fuel consumption, buckwheat, growth
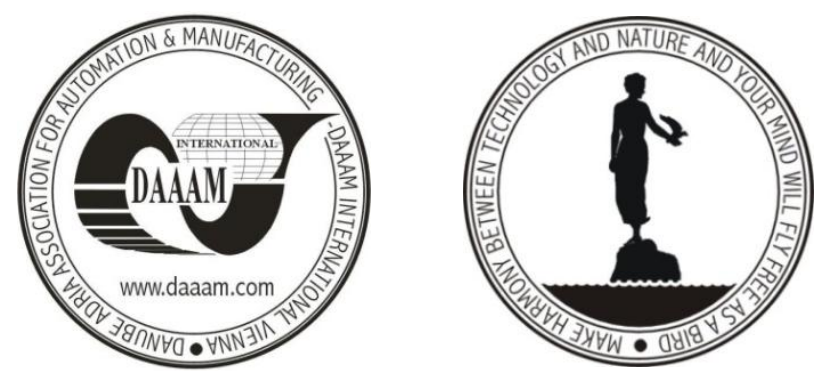

Authors' data: Assist. Prof. Dr. Vindis, P[eter]; Assoc. Prof. Stajnko, D[enis]; Assoc. Prof. Lakota, M[iran], University of Maribor, Faculty of Agriculture and Life Sciences, Pivola 10, SI-2311, Hoce, Slovenia, peter.vindis@um.si, miran.lakota@um.si,denis.stajnko@um.si.

This Publication has to be referred as: Vindis, P[eter]; Lakota, M[iran] \& Stajnko, D[enis] (2013) The Influence of Different Soil Cultivation on Fuel Consumption and the Growth of Buckwheat, Chapter 18 in DAAAM International Scientific Book 2013, pp. 361-370, B. Katalinic \& Z. Tekic (Eds.), Published by DAAAM International, ISBN 978-3-901509-94-0, ISSN 1726-9687, Vienna, Austria DOI: $10.2507 /$ daaam.scibook.2013.18 
Vindis, P.; Lakota, M. \& Stajnko, D.: The Influence of Different Soil Cultivation o...

\section{Introduction}

Soil tillage is the largest consumer of fuel in the production of crops. Today, due to high fuel prices many farmers abandon conventional treatment with ploughing and replace it with ripping treatments. Tillage is one of the oldest human activities; the tillage methods went through a period of increasingly changing. At the beginning of human civilization hunting and gathering dominated in agriculture, but with time, people began to develop various tools for soil tillage (Kopse \& Krajnc, 2005). Today on our farms two methods of soil tillage are mainly used: conventional tillage with plough and ripping without ploughing, but there is still a third way: direct sowing without tillage (Krajnc \& Kopse, 2005).

Due to increasing fuel prices and low sale prices of crops the farmers are forced to look for new ways to cut costs on the farm. In the basic soil tillage with ploughing the most fuel is needed, so some farmers have decided to abandon this tillage and replace it by new ripping tillage techniques (Bernik 2005).

In this study we try to answer the question which tillage method is best for the production of buckwheat. The experiment was performed on buckwheat (Fagopyrum esculentum L.), where yield depends on the preparation of the soil before sowing, as other agro-technical activities are minimally implemented. In the soil tillage for buckwheat there are many different issues related to the suitability and economy of production; in this study we want to find a solution so that the farmers can take decisions easier.

Šbül (2011) measured the fuel consumption when ploughing with 3 furrow plough PÖTTINGER SERVO III PLUS, which amounted to $29.3 \mathrm{l} / \mathrm{ha}$, with ripper UNIA KOS 3.0B to12.09 1/ha. The difference between them was $17.21 \mathrm{l} / \mathrm{ha}$. The working width of the plough was $1.26 \mathrm{~m}$ and working width of the ripper was $3.0 \mathrm{~m}$. Measurements did not take into account the fuel consumption during turning at the end of the field.

The fuel consumption was also influenced by the wheel slip, which can be reduced by a lower pressure in the tires. When ploughing fields with 0.8 bar tire pressure the fuel consumption was $21.87 \mathrm{l} / \mathrm{ha}$, at a pressure of $2.4 \mathrm{bar}$ the fuel consumption was $25.78 \mathrm{l} / \mathrm{ha}$. The measurements were performed with the standard tractor Deutz Fahr K100 and 3-furrow plough PÖTTINGER SERVO 25-302. The working width of the plough was $1.2 \mathrm{~m}$ (Kacijan, 2010).

The main purpose of this research is to determine the difference in fuel consumption when ploughing and ripping. Since it is known that the ripping consumes less fuel than ploughing, we wanted to determine how tillage affects the emergence of buckwheat plants, weeds and residues of rape. At the same time we tried to determine how tillage affects the size of the plant.

\section{Methods}

For the experiment of emergence and intensity of growth of buckwheat the large part of the 4.7 ha arable land was used (Figure 1). The field is located in the centre of the village Hajdose in the municipality of Hajdina. The local name of the field is 
'Home'. The soil of the field is clay-sand, which means that it is airy, easy to process and has a low moisture retention.

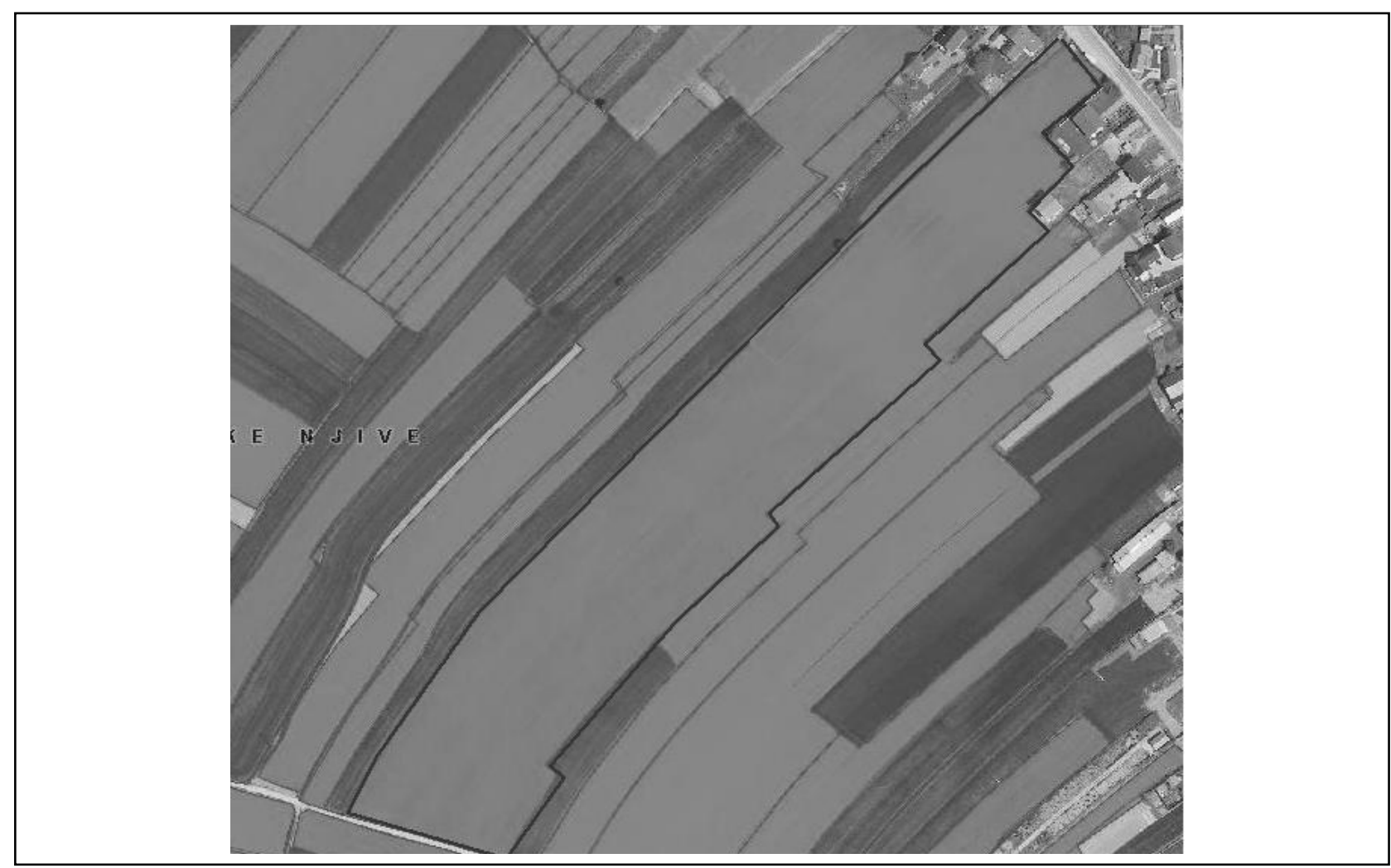

Fig. 1. The field on which the experiment of emergence and intensity of growth was performed (GERK 2012)

For the experiment the buckwheat (Fagopyrum esculentum L.) autochthonous variety "Darja", seed producer Ljubljana, was sown. Buckwheat is sown to a depth of 2-3 cm, in the dry season a little deeper i.e. up to $4 \mathrm{~cm}$. In the well-stocked soil fertilization is not required; where the soil is less stocked, with nutrients and addition of $50 \mathrm{~kg}$ of nitrogen $(\mathrm{N}), 50 \mathrm{~kg}$ of phosphorus $\left(\mathrm{P}_{2} \mathrm{O}_{5}\right)$ and $50 \mathrm{~kg}$ of potassium $\left(\mathrm{K}_{2} \mathrm{O}\right)$ per hectare.

The experiment was conducted on heavy soils (evterical mineral medium strong $70 \%$, evterical mineral strong 30\%). The coordinates of the experiment are $15^{\circ} 40^{\prime} 36^{\prime \prime}$ East and 4635 '58" north. Soil type: hypogley (calcaric gleysol), soil texture: clay. The water content in the soil at the time of the experiment was 20.3\% (Stanjko et al., 2009).

Soil was ploughed to the average depth of $\mathrm{a}=22 \mathrm{~cm}$, while ripping took place at an average depth of $\mathrm{a}=15 \mathrm{~cm}$.

\section{Machinery used in the Experiment}

For ripping and ploughing the tractor New Holland 6020 Delta $(\mathrm{P}=82 \mathrm{~kW})$, year 2008 with four-wheel drive was used. For sowing the tractor New Holland, year 2001, model TN75D $(\mathrm{P}=53 \mathrm{~kW})$ was used. For chiselled soil tillage the ripper Lemken Smaragd 9 (Fig. 2, left) was used, which has $\mathrm{Br}=2.7 \mathrm{~m}$ working width. 
Vindis, P.; Lakota, M. \& Stajnko, D.: The Influence of Different Soil Cultivation o...

Buckwheat was sown with mechanical seed drill for continuous sowing Lemken Saphir 7 Autoload (Figure 2, right). Arable land was ploughed with a four-furrow Lemken plough VariOpal 6 (Figure 3).

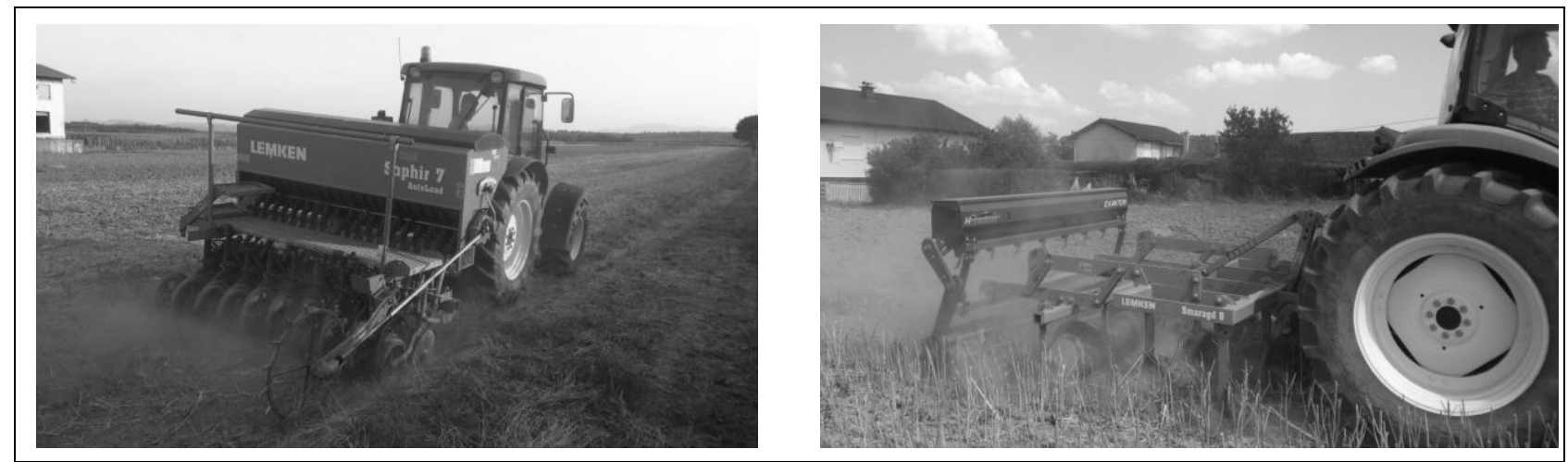

Fig. 2. Ripper Lemken Smaragd 9 (left) and seed drill Lemken Saphir 7 Autoload (right)

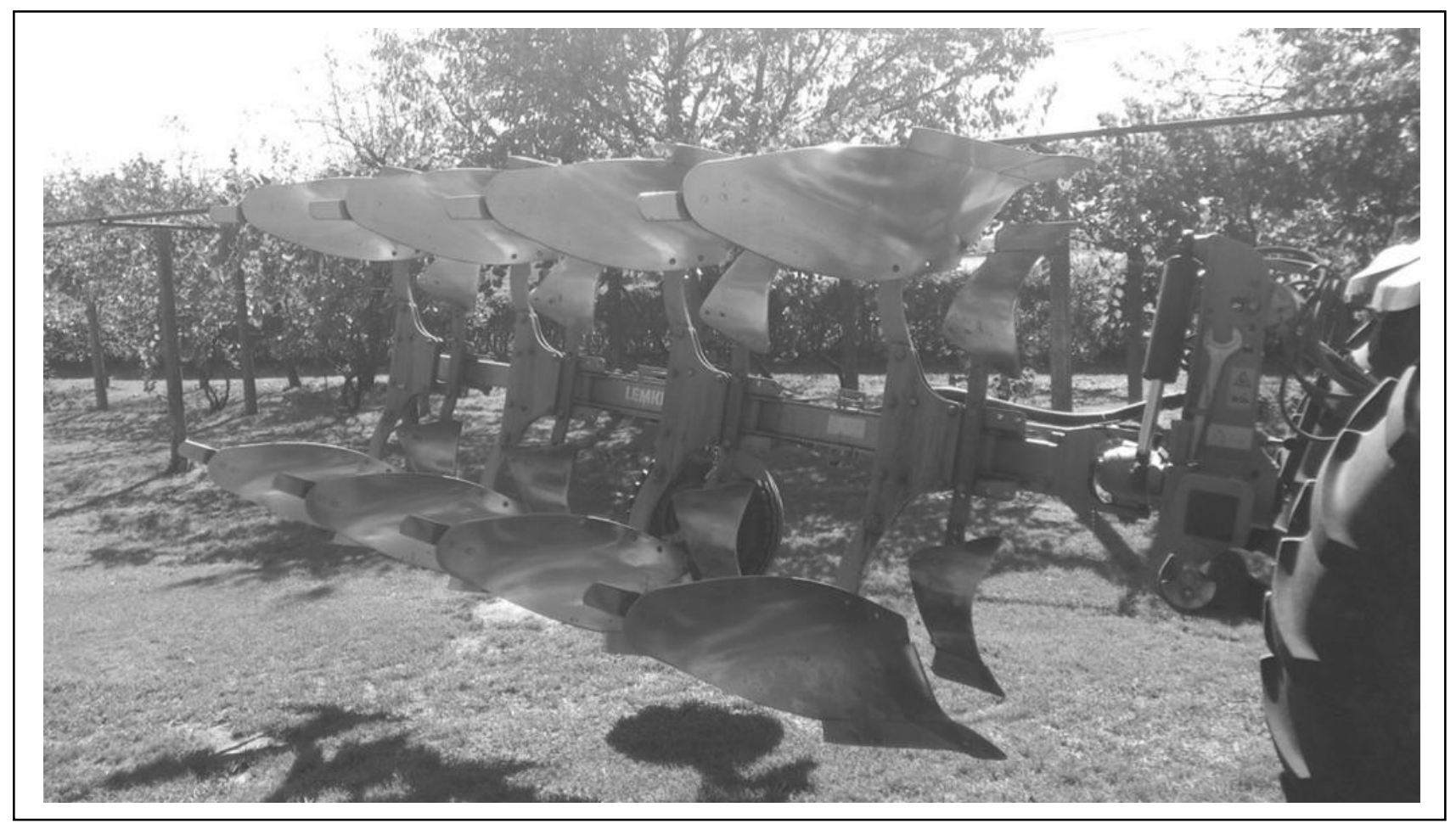

Fig. 3. Lemken plough VariOpal 6

\subsection{Measurement of the Fuel Consumption}

The fuel consumption was measured so that before tillage the fuel tank was filled to the brim and then after work, once again topped up. For filling up the tank the measuring cylinder was used $(1000 \mathrm{ml})$.

Measurements were performed on eight lots, which were divided into two groups (Table 1). In the first group, we measured the fuel consumption with ripping and in the second group consumption during the ploughing. The size of arable land between the two groups is roughly in equal proportion; within each group there are some differences. 


\begin{tabular}{|c|c|c|c|}
\hline \multirow{2}{*}{ REPEAT } & COMMON NAME & GERK & PLOT SIZE (ha) \\
\hline \multicolumn{4}{|c|}{ SURFACES TREATED WITH RIPPER } \\
\hline 1. & PRI SABINI & 4910641 & 0,24 \\
\hline 2. & SKLADOVO & 4780681 & 0,54 \\
\hline 3. & KOTEC & 1190357 & 0,84 \\
\hline 4. & KOMASACIJA & 4789122 & 1,28 \\
\hline \multicolumn{5}{|c|}{ SURFACES TREATED WITH PLOUGHING } \\
\hline 1. & PRI KANALU & 4072897 & 0,25 \\
\hline 2. & PRELOGE & 1190353 & 0,48 \\
\hline 3. & KOTEC & 1190357 & 0,85 \\
\hline 4. & LOG & 3205140 & 1,27 \\
\hline
\end{tabular}

Tab. 1. Surface used for the measurement of fuel consumption in ripping and ploughing

\subsection{Determination of Emergence and Height of Buckwheat}

On $7^{\text {th }}$ of July 2012 the buckwheat was sowed; on all surfaces the sowing norm was equivalent to $95 \mathrm{~kg}$ of seed per hectare. The emergence of the first plants appeared about five days after sowing (07/12/2012), but we postponed counting additional two weeks for full emergence of all plants and weeds.

The experiment was conducted on $25^{\text {th }}$ of July 2012 . We made a wooden frame $50 \times 50 \mathrm{~cm}$ and randomly placed it on the surface at scattered places (Figure 4) and then counted the number of emerged plants of buckwheat, rape and weeds. Rape had been sown before buckwheat, so we have defined rape specifically so that the importance of ploughing crop residues is better illustrated. Such experiment was effected on twenty randomly selected locations on each surface. The measurements were repeated twice in intervals of 14 days $\left(8^{\text {th }}\right.$ and $22^{\text {th }}$ of August 2012) (Brodnjak, 2012).

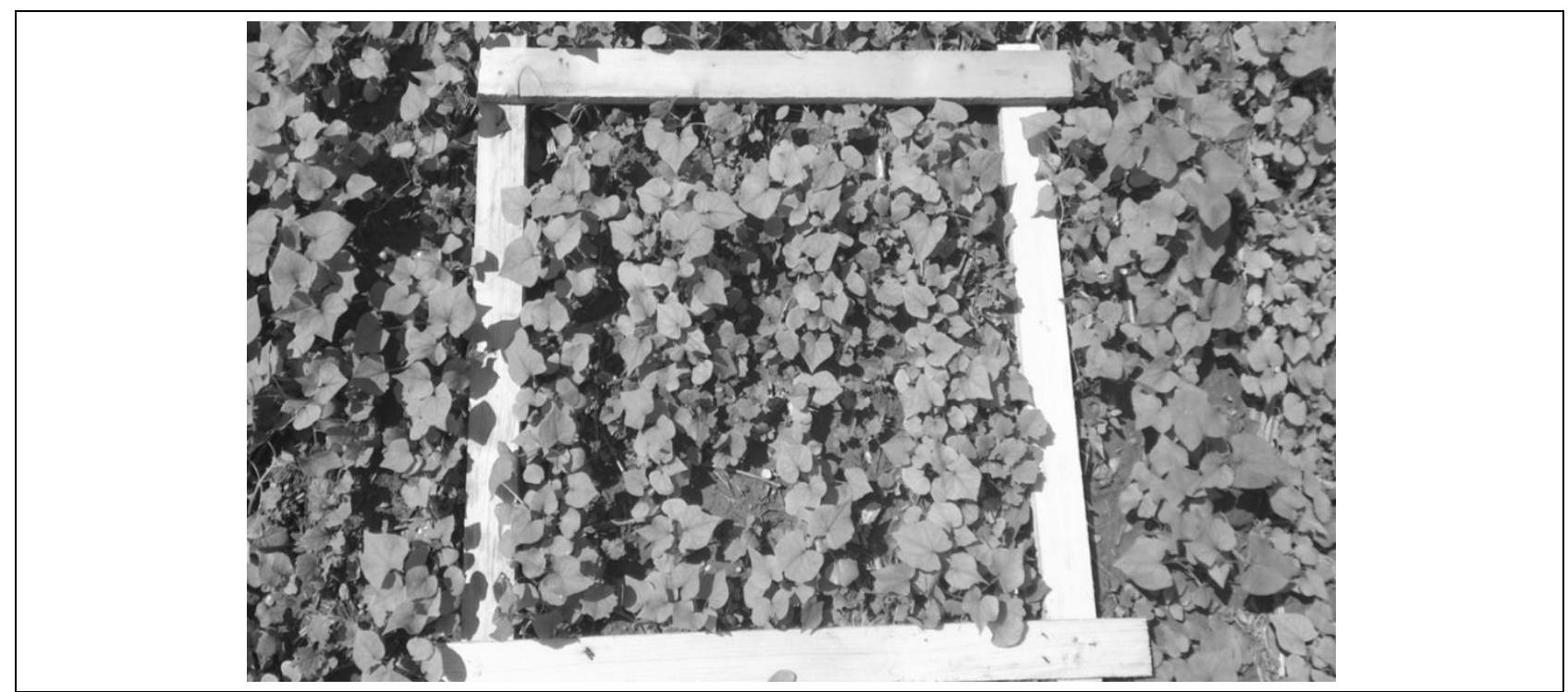

Fig. 4. Counting the number of plants on the surface treated with ripper 
Vindis, P.; Lakota, M. \& Stajnko, D.: The Influence of Different Soil Cultivation o...

From measurements the following parameters were calculated:

- Average fuel consumption in liters per hectare (1/ha),

- Average time spent in minutes per hectare $(\mathrm{min} / \mathrm{ha})$,

- Labor productivity in hectares per hour (ha/h),

- Density of plants per square meter (plants $/ \mathrm{m}^{2}$ ),

- The average size of the plants $(\mathrm{cm})$.

\section{Results with Discussion}

\subsection{Fuel and Time Consumption in Ripping}

Fuel and time consumption for ripping the soil were measured on a total of $\mathrm{A}=$ 2.9 ha of arable land (Table 2). The maximum consumption was on the lowest surface ('PRI SABINI') $\mathrm{Q}=12.5 \mathrm{l} / \mathrm{ha}$ and the smallest on the largest area ('KOMASACIJA') Q=10 1/ha. A similar picture is also reflected in the results of spent time; the most time is spent for tillage of the smallest area $(\mathrm{t}=50 \mathrm{~min} / \mathrm{ha})$ and the least time for tillage of the largest area $(t=46.9 \mathrm{~min} / \mathrm{ha})$. For the tillage of all surfaces in the average $\mathrm{Q}=11.26$ liters per hectare and $\mathrm{t}=48.45$ minutes per hectare were spent. The difference in fuel and the time consumption is due to the form of plots. Large plots are longer and narrower, so much turning is not needed.

\begin{tabular}{|c|c|c|c|c|c|}
\hline $\begin{array}{c}\text { COMMON } \\
\text { NAME }\end{array}$ & $\begin{array}{c}\text { PLOT } \\
\text { SIZE } \\
\text { (ha) }\end{array}$ & $\begin{array}{c}\text { FUEL } \\
\text { CONSUMPTION } \\
(\mathrm{L})\end{array}$ & $\begin{array}{c}\text { TIME } \\
\text { CONSUMPTION } \\
\text { (min) }\end{array}$ & $\begin{array}{c}\text { FUEL } \\
\text { CONSUMPTION } \\
(1 / \mathrm{ha})\end{array}$ & $\begin{array}{c}\text { TIME } \\
\text { CONSUMPTION } \\
\text { (min/ha) }\end{array}$ \\
\hline PRI SABINI & 0,24 & 3 & 12 & 12,5 & 50 \\
\hline SKLADOVO & 0,54 & 6,2 & 26 & 11,48 & 48,1 \\
\hline KOTEC & 0,84 & 9,3 & 41 & 11,07 & 48,8 \\
\hline KOMASACIJA & 1,28 & 12,8 & 60 & 10 & 46,9 \\
\hline TOGETHER & $\mathbf{2 , 9}$ & $\mathbf{3 1 , 3}$ & $\mathbf{1 3 9}$ & & \\
\hline AVERAGE & & & & $\mathbf{1 1 , 2 6}$ & $\mathbf{4 8 , 4 5}$ \\
\hline
\end{tabular}

Tab. 2. Fuel and time consumption in ripping

\subsection{Fuel and Time Consumption in Ploughing}

Table 3 shows the measured fuel and time consumption when ploughing. Results show that the fuel and time consumption in ploughing is higher than in ripping. For the measurements a total of 2.85 hectares of arable land and 87.7 litres of fuel were spent. The highest fuel consumption was measured at the smallest field 'PRI KANALU' 31.6 1/ha, the smallest consumption was achieved at the biggest field 'LOG' 30.16 1/ha. We spent 72 minutes to tillage one hectare at the smallest field and 64.6 minutes at the biggest field. Average fuel consumption was for $276 \%$ higher than in ripping and amounted to $31.51 /$ ha, time consumption was for $139.9 \%$ higher and amounted to $67.8 \mathrm{~min} / \mathrm{ha}$. 


\begin{tabular}{|c|c|c|c|c|c|}
\hline $\begin{array}{c}\text { COMMON } \\
\text { NAME }\end{array}$ & $\begin{array}{c}\text { PLOT } \\
\text { SIZE } \\
\text { (ha) }\end{array}$ & $\begin{array}{c}\text { FUEL } \\
\text { CONSUMPTION } \\
(\mathrm{L})\end{array}$ & $\begin{array}{c}\text { TIME } \\
\text { CONSUMPTION } \\
(\mathrm{min})\end{array}$ & $\begin{array}{c}\text { FUEL } \\
\text { CONSUMPTION } \\
(1 / \mathrm{ha})\end{array}$ & $\begin{array}{c}\text { TIME } \\
\text { CONSUMPTION } \\
(\mathrm{min} / \mathrm{ha})\end{array}$ \\
\hline PRI KANALU & 0,25 & 7,9 & 18 & 31,6 & 72 \\
\hline PRELOGE & 0,48 & 15 & 33 & 31,25 & 68,8 \\
\hline KOTEC & 0,85 & 26,5 & 56 & 31,18 & 65,9 \\
\hline LOG & 1,27 & 38,3 & 82 & 30,16 & 64,6 \\
\hline TOGETHER & $\mathbf{2 , 8 5}$ & $\mathbf{8 7 , 7}$ & $\mathbf{1 8 9}$ & & $\mathbf{3 1 , 0 5}$ \\
\hline AVERAGE & & & & $\mathbf{6 7 , 8}$ \\
\hline
\end{tabular}

Tab. 3. Fuel and time consumption in ploughing

\subsection{Fuel and Time Consumption in Sowing}

If comparing the fuel and the time consumption for sowing on ploughed or ripped surface, these two parameters are not so much different (Table 4). For comparison the smallest and largest field in both tillage methods were used. Average fuel consumption in sowing on rippened soil was $5.57 \mathrm{l} / \mathrm{ha}$ and in ploughed soil was $5.63 \mathrm{l} / \mathrm{ha}$. A similar picture was obtained also in time consumption; for sowing on the ripped surface $44.79 \mathrm{~min} / \mathrm{ha}$ were spent and on the ploughed soil $44.87 \mathrm{~min} / \mathrm{ha}$. From the data of the size of the lot and time consumption at ploughing, ripping and sowing the productivity of individual machines was calculated. The productivity of ripper was $1.24 \mathrm{ha} / \mathrm{h}$, the productivity of the plough was $0.89 \mathrm{ha} / \mathrm{h}$ and the productivity of sowing drill was $1.34 \mathrm{ha} / \mathrm{h}$.

Figure 5 shows the comparison between fuel consumption (1/ha) in ploughing, ripping and sowing.

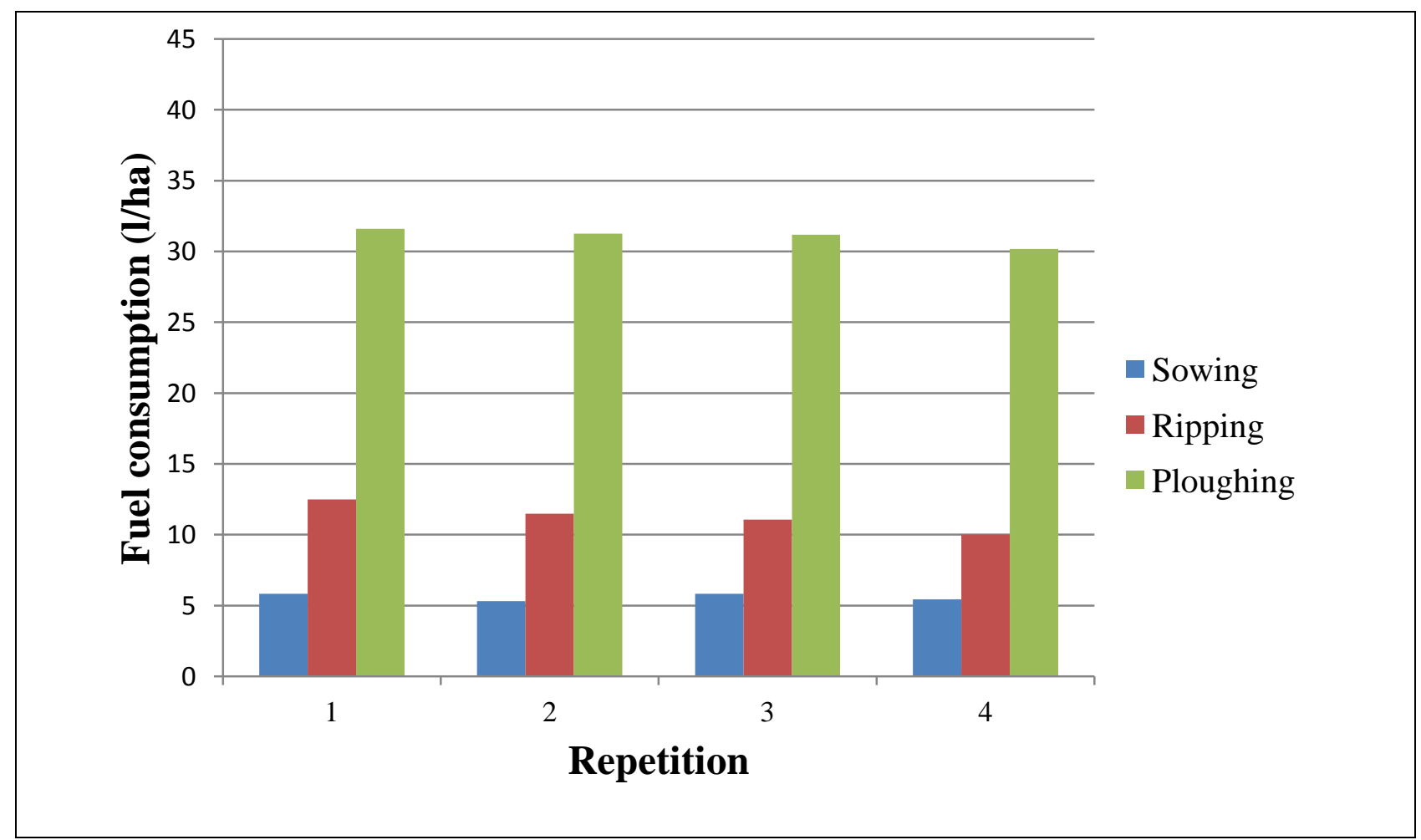

Fig. 5. Fuel consumption in ploughing, ripping and sowing 
Vindis, P.; Lakota, M. \& Stajnko, D.: The Influence of Different Soil Cultivation o...

\begin{tabular}{|c|c|c|c|c|c|}
\hline $\begin{array}{c}\text { COMMON } \\
\text { NAME }\end{array}$ & $\begin{array}{l}\text { PLOT } \\
\text { SIZE } \\
\text { (ha) }\end{array}$ & $\begin{array}{c}\text { FUEL } \\
\text { CONSUMPTION } \\
\text { (L) }\end{array}$ & $\begin{array}{c}\text { TIME } \\
\text { CONSUMPTION } \\
\text { (min) }\end{array}$ & $\begin{array}{c}\text { FUEL } \\
\text { CONSUMPTION } \\
(1 / \mathrm{ha})\end{array}$ & $\begin{array}{c}\text { TIME } \\
\begin{array}{c}\text { CONSUMPTION } \\
(\mathrm{min} / \mathrm{ha})\end{array}\end{array}$ \\
\hline \multicolumn{6}{|c|}{ SOWING ON RIPPED SURFACE } \\
\hline PRI SABINI & 0,24 & 1,4 & 11 & 5,83 & 45,83 \\
\hline KOMASACIJA & 1,28 & 6,8 & 56 & 5,31 & 43,75 \\
\hline AVERAGE & & & & $\mathbf{5 , 5 7}$ & 44,79 \\
\hline \multicolumn{6}{|c|}{ SOWING ON PLOUGHED SURFACE } \\
\hline PRI KANALU & 0,25 & 1,4 & 12 & 5,83 & 48 \\
\hline LOG & 1,27 & 6,9 & 53 & 5,43 & 41,73 \\
\hline AVERAGE & & & & 5,63 & 44,87 \\
\hline
\end{tabular}

Tab. 4. Fuel and time consumption in sowing

\subsection{Emergence of Plants}

Emergence of buckwheat after sowing was $68.4 \%$. On $0.25 \mathrm{~m}^{2} 45.15$ buckwheat plants, 14.2 plants of rapeseed and 102 weeds grew. On the surface of $0.25 \mathrm{~m}^{2}$, which was treated before sowing with the ripper an average of 47.75 buckwheat plants were counted, this means that emergence of buckwheat was $72.3 \%$. On the surface of 0.25 $\mathrm{m}^{2} 10.1$ plants of rape and 2.85 plants of weeds were counted. Emergence of the plants on the surface treated with a plough was $90.1 \%$. 59,45 buckwheat plants and 0.05 plants of weed on $0.25 \mathrm{~m}^{2}$ were counted.

To summarize the above results, we can see that the emergence of buckwheat on the ploughed surface was for $17.8 \%$ better than on the ripped surface and for $21.7 \%$ better than in direct sowing. Also on the tilled surface in 20 repetitions any rape crop was not found, while only one weed was found. From this we can conclude that the best tillage is ploughing.

However, the effect of ripper cannot be completely ignored, since on the surface for $28.9 \%$ less plants of rape and $44.1 \%$ less weeds appeared than at direct sowing.

\subsection{The Average Plant Height}

Different soil tillage affected the intensity of growth (Berk et al., 2011). The height of buckwheat was measured on the $25^{\text {th }}$ of July, $8^{\text {th }}$ of August and $16^{\text {th }}$ of August 2012. The highest plants were on ploughed surface.

In the first measurement the average height of buckwheat was measured: at direct sowing the height was $22,21 \mathrm{~cm}$, at ripping the height was $23.24 \mathrm{~cm}$ and at ploughing the height was $31.07 \mathrm{~cm}$. In the second measurement the height for direct sowing 40,02 cm was measured, at ripping the height was $49.51 \mathrm{~cm}$ and at ploughing the height was $70.07 \mathrm{~cm}$.

Similar results as in the first two measurements were also measured at the third one. Measured heights were: at direct sowing $70.21 \mathrm{~cm}$, at ripping $80.45 \mathrm{~cm}$ and at ploughing $99.75 \mathrm{~cm}$ (Figure 6). 


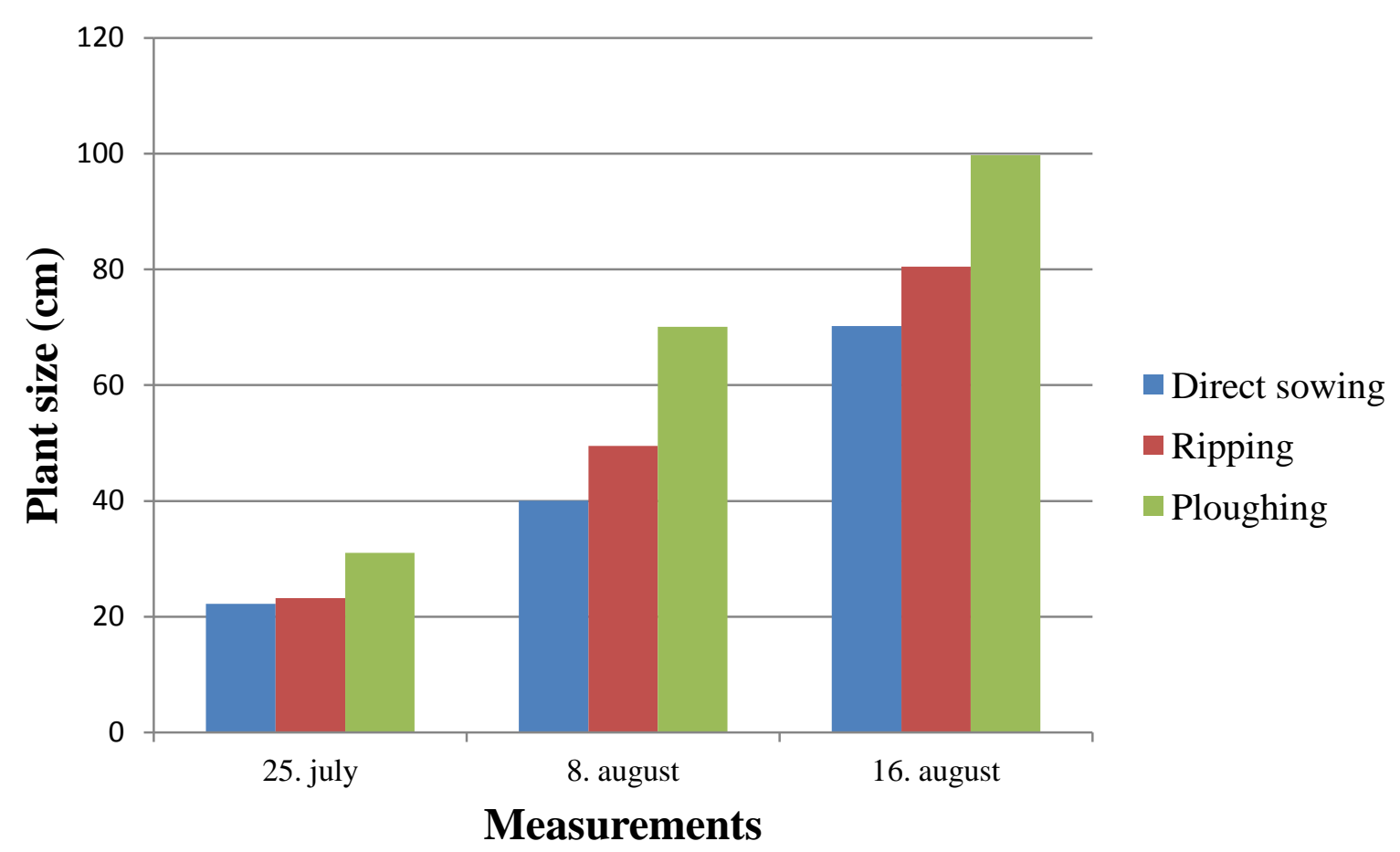

Fig. 6. Size of plants in different processing and individual measurements

\section{Conclusion}

On the basis of the measurements it can be concluded:

- Average fuel consumption at soil ripping was $11.26 \mathrm{l} / \mathrm{ha}$ and average fuel consumption at conventional tillage with plough was $31.05 \mathrm{l} / \mathrm{ha}$.

- Time consumption for tillage of one hectare of land was 48.45 minutes at ripping and at ploughing 67.8 minutes. Tillage time at ripping was for $39.6 \%$ shorter than at ploughing. Labour productivity at ripping was $1.25 \mathrm{ha} / \mathrm{h}$ and at ploughing it was 0.90 ha/h.

- For smaller areas on the average more time and fuel are needed for tillage of one hectare area than in larger areas. Average fuel consumption at ripping of minimum area $(0.24 \mathrm{ha})$ was $12.5 \mathrm{l} / \mathrm{ha}$, at ripping the largest area $(1.27 \mathrm{ha})$ was $10.0 \mathrm{l} / \mathrm{ha}$. Average consumption at ploughing the minimum area $(0.25 \mathrm{ha})$ was $31.6 \mathrm{l} / \mathrm{ha}$ and at ploughing the largest ares (1.28 ha) $30.16 \mathrm{l} / \mathrm{h}$.

- The best emergence of buckwheat was on the tilled surface $90.1 \%$, for $17.8 \%$ worse it was at ripping and for $21.7 \%$ worse at direct sowing.

- On the ploughed surface there was a negligible number of weeds, since we find in twenty repetitions only one weed, while on average on ripped surface 10,1 plants of rape and 2.85 weed plants on $0.25 \mathrm{~m}^{2}$ occurred. At direct sowing on the average 14.2 plants of rape and 5.1 weeds on $0.25 \mathrm{~m}^{2}$ were counted. 
Vindis, P.; Lakota, M. \& Stajnko, D.: The Influence of Different Soil Cultivation o...

- Maximum growth height of buckwheat was reached on the ploughed surface. In all three measurements the plants were on average higher than at ripping and direct sowing. In the first measurement ( $25^{\text {th }}$ of July 2012$)$ the average plant heights were: $22,21 \mathrm{~cm}$ at direct sowing, $23,24 \mathrm{~cm}$ at ripping and $31,07 \mathrm{~cm}$ on the ploughed surface.

- The results of the second measurement of the buckwheat height ( $8^{\text {th }}$ August 2012) were: $40,02 \mathrm{~cm}$ at direct sowing, $49,51 \mathrm{~cm}$ at ripping and $70,07 \mathrm{~cm}$ on the ploughed surface. Heights in the third measurement $\left(16^{\text {th }}\right.$ August 2012) were: $70.21 \mathrm{~cm}$ at direct sowing, $80,45 \mathrm{~cm}$ at ripping and $99,75 \mathrm{~cm}$ on the ploughed surface.

- Future research will focus on improving chiselling tillage with ripping. The main topic is to find new tools for ripping, which will give better quality of work and reduce the fuel and time consumption. Reducing fuel and time consumption reduce the costs of production. Producers of agricultural machinery offer a lot of products on the market and we will try to find out, which gives the better results at soil tillage.

\section{References}

Berk, P., Vindis, P., Lakota, M., Ocepek, M \& Rakun, J. (2011). Artificial neural network for identification of large letters of the alphabet. DAAAM International Scientific Book, Vienna: Daaam international publishing, 401-408

Bernik, R. (2005). Engineering in agriculture (soil tillage, seeding and fertilization). Ljubljana, Department of Agronomy, Biotechnical Faculty in Ljubljana: 7-81.

Brodnjak, M. (2012). The influence of different ways of soil cultivation on fuel consumption and the growth of buckwheat. University of Maribor, Faculty of Agriculture and Life sciences (thesis)

Kacijan, A. (2010). The effect of pressure in tyres on the sleep and fuel consumption during ploughing. University of Maribor, Faculty of Agriculture and Life sciences (thesis)

Kopse, I. \& Krajnc, N. (2005). Heating with wood, Forest Service of Slovenia, Ljubljana

Krajnc, N. \& Kopse, I. (2005). Wood - renewable and environmentally friendly energy source, Forest Service of Slovenia, Ljubljana. Official Journal RS, No. 42/2002, day 15. 5. 2002

Šbül, P. (2011). Influence of different basic soil cultivation techniques for maize sowing on fuel consumption and slipping. University of Maribor, Faculty of Agriculture and Life sciences (thesis)

Stajnko, D.; Vindis, P. \& Mursec, B. (2009). Reduction of $\mathrm{CO}_{2}$ emission in production of corn in Slovenia. DAAAM International Scientific Book, Vienna, DAAAM International Publishing, 573-586 